\title{
Correction to: Chemopreventive effect of Betulinic acid via mTOR -Caspases/Bcl2/Bax apoptotic signaling in pancreatic cancer
}

Yangyang Guo, Hengyue Zhu, Min Weng, Cheng Wang ${ }^{*}$ (D) and Linxiao Sun ${ }^{*}$

\section{Correction to: BMC Complement Med Ther 20, 178 (2020)}

https://doi.org/10.1186/s12906-020-02976-7

Following publication of the original article [1], the authors reported that a mistake in Fig. $1 \mathrm{~b}$ and $\mathrm{d}$ and the group is not marked in Fig. $6 \mathrm{~b}$ and d.

The original article [1] has been updated.

Published online: 26 April 2021

\section{Reference}

1. Guo Y, Zhu H, Weng M, et al. Chemopreventive effect of Betulinic acid

via mTOR -Caspases/Bcl2/Bax apoptotic signaling in pancreatic cancer. BMC Complement Med Ther. 2020;20:178 https://doi.org/10.1186/s12

906-020-02976-7.

The original article can be found online at https://doi.org/10.1186/s12906020-02976-7.

* Correspondence: wangchengmandy@126.com; sunlinxiao@wmu.edu.cn Key Laboratory of Diagnosis and Treatment of Severe Hepato-Pancreatic Diseases of Zhejiang Province, Zhejiang Provincial Top Key Discipline in Surgery, Wenzhou Medical University First Affiliated Hospital, Wenzhou,

Zhejiang, China

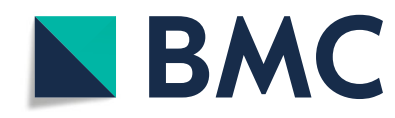

(c) The Author(s). 2021 Open Access This article is licensed under a Creative Commons Attribution 4.0 International License, which permits use, sharing, adaptation, distribution and reproduction in any medium or format, as long as you give appropriate credit to the original author(s) and the source, provide a link to the Creative Commons licence, and indicate if changes were made. The images or other third party material in this article are included in the article's Creative Commons licence, unless indicated otherwise in a credit line to the material. If material is not included in the article's Creative Commons licence and your intended use is not permitted by statutory regulation or exceeds the permitted use, you will need to obtain permission directly from the copyright holder. To view a copy of this licence, visit http://creativecommons.org/licenses/by/4.0/. The Creative Commons Public Domain Dedication waiver (http://creativecommons.org/publicdomain/zero/1.0/) applies to the data made available in this article, unless otherwise stated in a credit line to the data. 


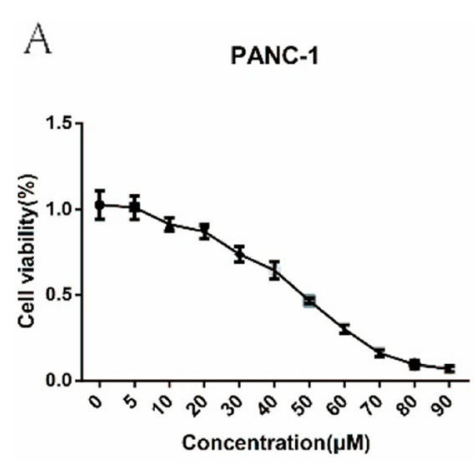

B

PANC-1

C

SW1990
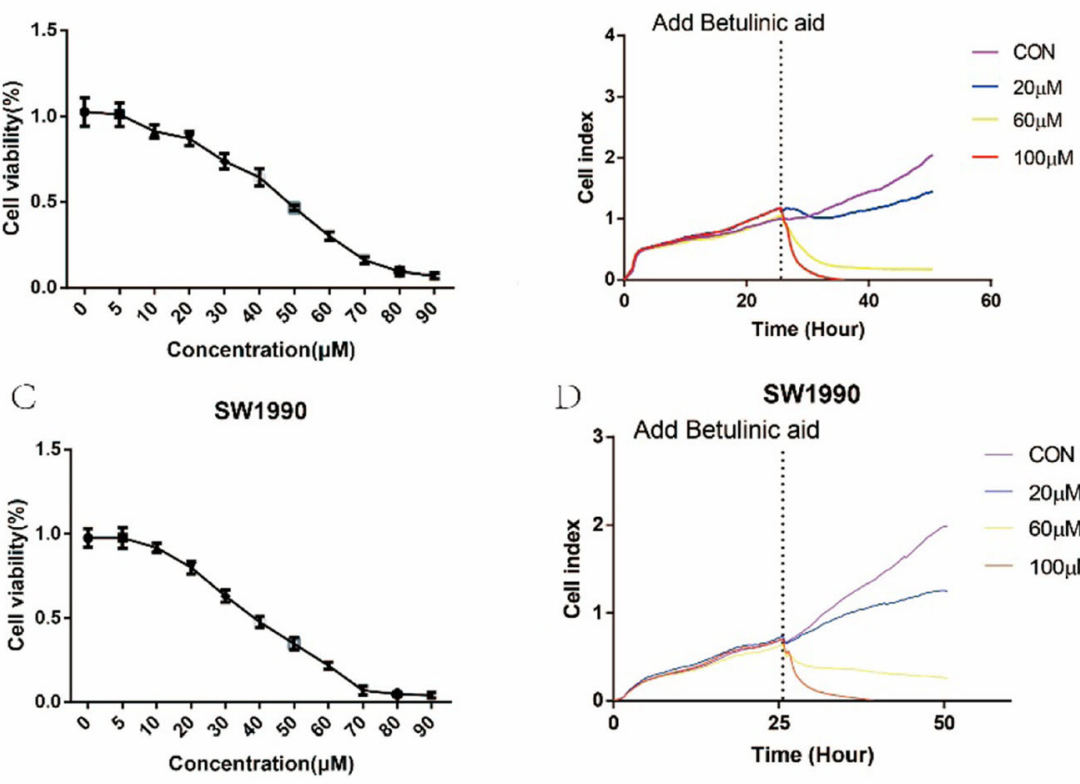

1)

SW1990

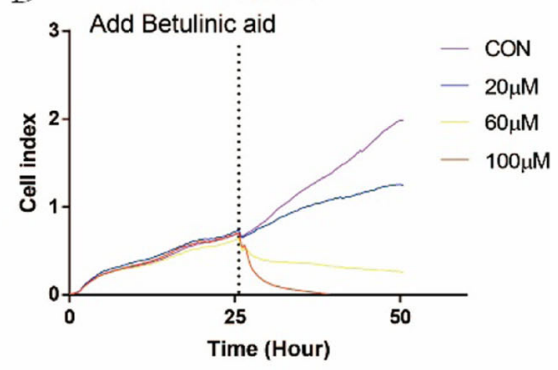

E

DAPI

Ki67

Merge

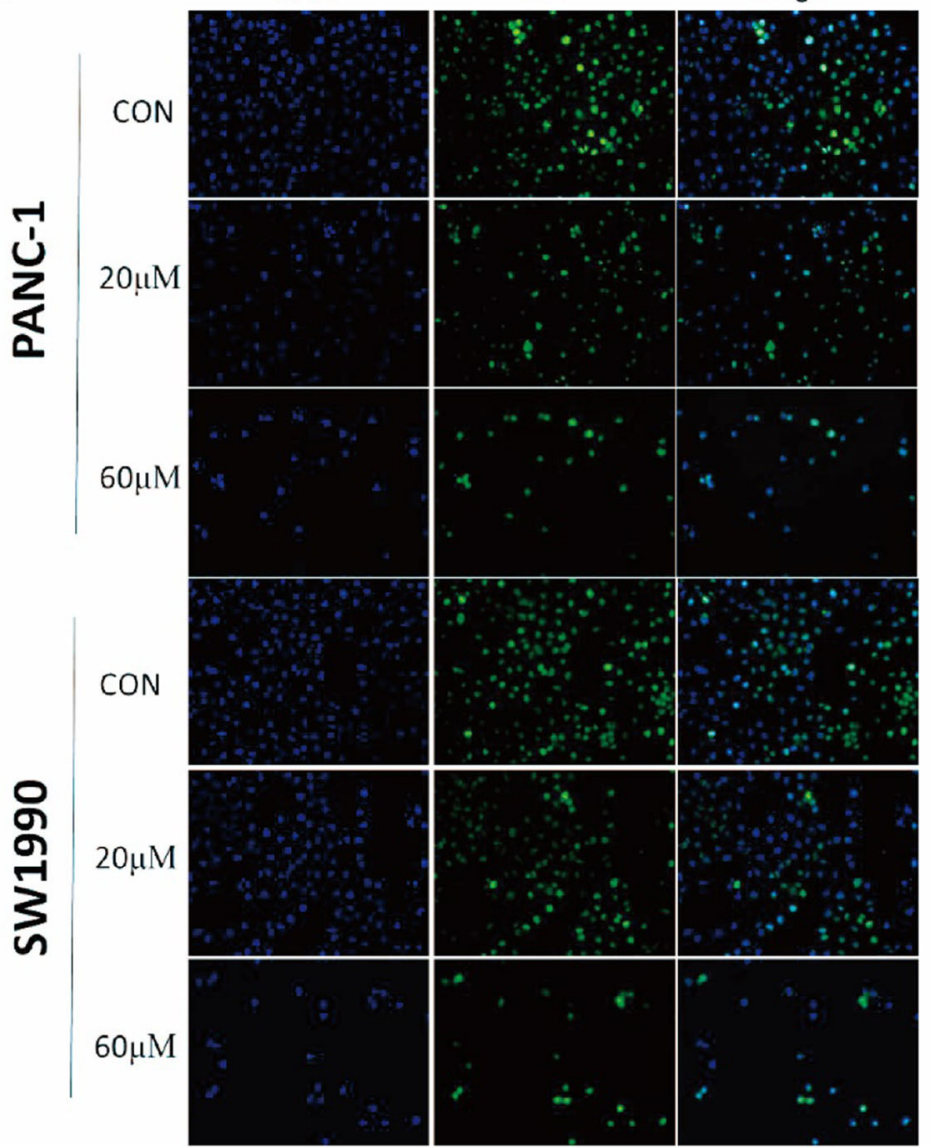

Fig. 1 (See legend on next page.) 
(See figure on previous page.)

Fig. 1 Betulinic acid inhibits PANC-1 and SW1990 cells proliferation. CCK8 assay of PANC-1 (a) and SW1990 (c) cells incubated with $5 \mu$ M,10 $\mu$ M, $20 \mu \mathrm{M}, 30 \mu \mathrm{M}, 40 \mu \mathrm{M}, 50 \mu \mathrm{M}, 60 \mu \mathrm{M}, 70 \mu \mathrm{M}, 80 \mu \mathrm{M}, 90 \mu \mathrm{M}$. Betulinic acid or an equal volume of DMEM medium for $24 \mathrm{~h}$. Label-free Real-time

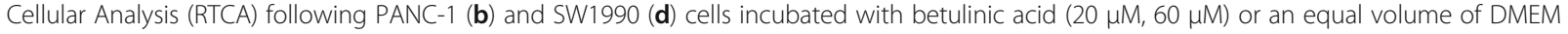

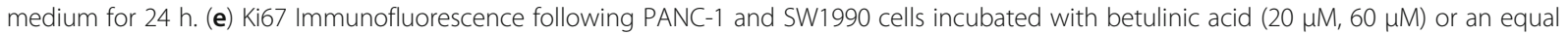
volume of DMEM medium for $24 \mathrm{~h}$
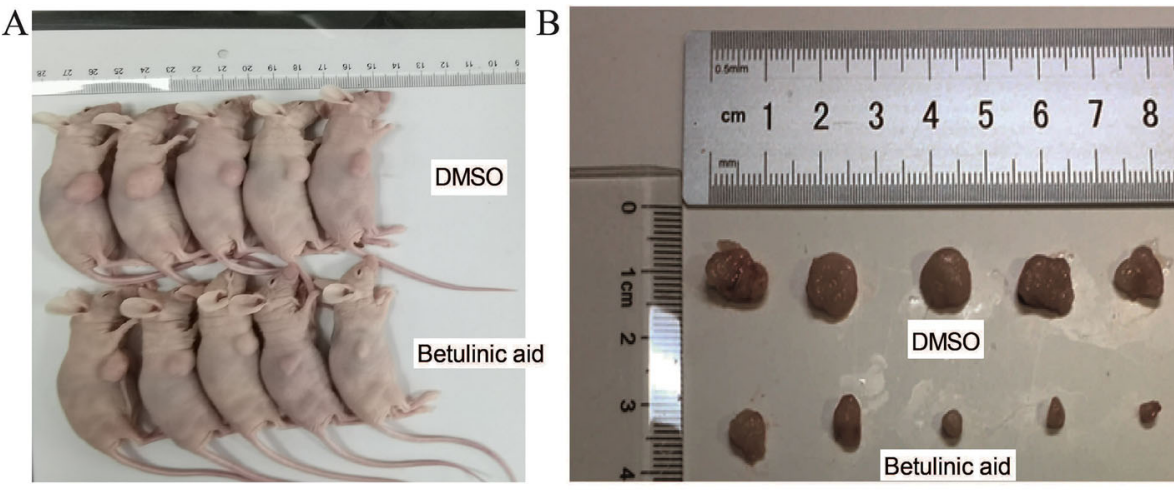

$\mathrm{C}$
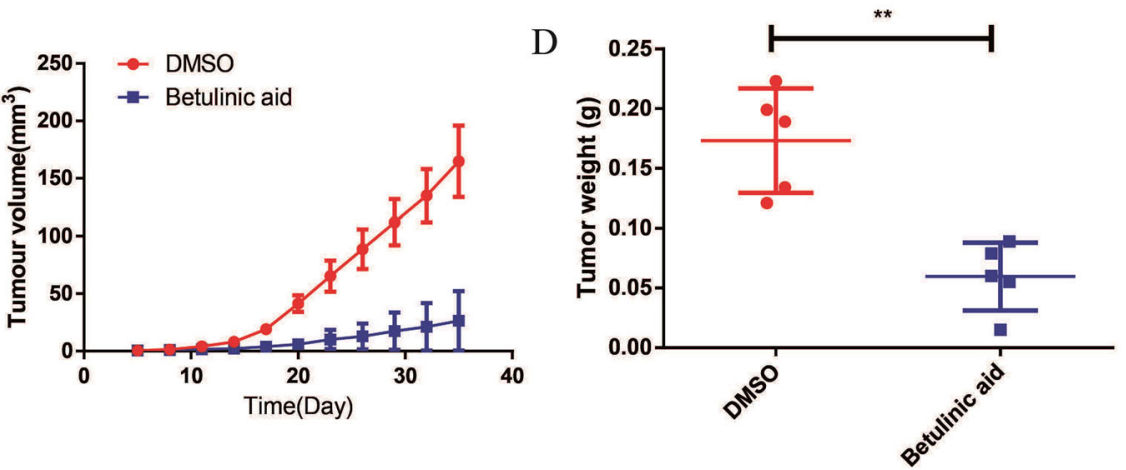

$\mathrm{E}$

\section{DMSO}

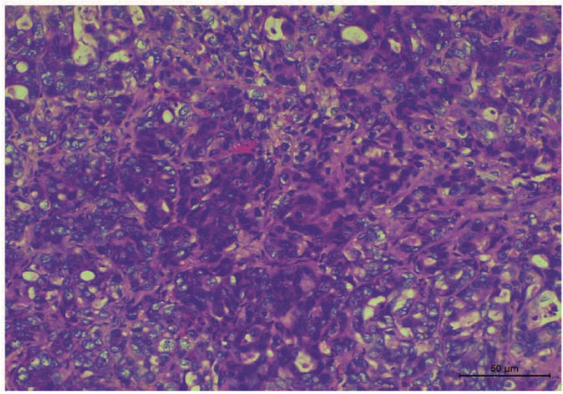

Betulinic acid

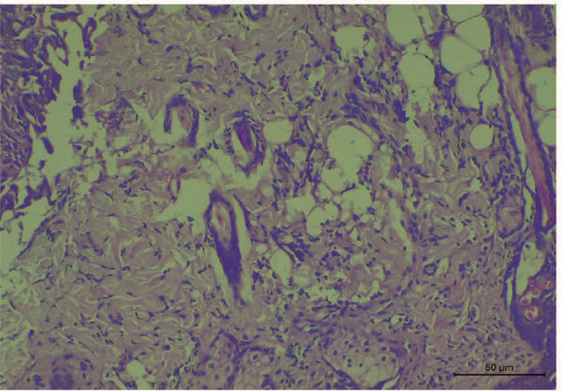

Fig. 6 Betulinic acid inhibits tumor growth of cell xenografts in nude mice. To further verify the effect of the Betulinic acid on PDAC cells, PANC-1 cells xenograft tumors were treated with Betulinic acid. When the diameter of the tumors reached $1 \mathrm{~mm}$, the mice were randomly divided to two groups with five mice in each group. After 30 days of treatment, the mice were killed (a) and the tumors were exfoliated (b). The tumor volume (c) was measured every three day for 30 days. Tumors weight (d) was measured after tumors exfoliated. e HE stain showed that Betulinic acid significantly inhibits tumor growth of cell xenografts in nude mice. One-way ANOVA with Tukey's multiple comparison tests was utilized to analyze the subcutaneous tumor growth. All the experiments were performed in triplicate and the data are presented as the mean \pm SD. The $t$-test was used for data analysis. ${ }^{*} P<0.05,{ }^{*} P<0.01$ 